\title{
New Market, New Challenge, New Opportunity (2) -User Context Research
}

\author{
Jiang Jiehui and Prabhu Kandachar \\ Faculty of Industrial Design Engineering, Delft University of Technology, the Netherlands
}

\begin{abstract}
China has a largest population in the world (1.3Billion) and 0.9 Billion is rural population. Most of rural people earn less than US\$3/day, and they are called "Base of the economic pyramid (BoP)". A new research project has been initiated on "The Healthcare Design for China Rural BoP" to the PhD of first author. This paper is about one part of this research: user context research. Two main processes will be introduced in this step: Qualitative research and quantitative research. Some healthcare needs in China rural like "Cancer early detection" has been found as the insights of this research.
\end{abstract}

Key words - Rural healthcare, Base of the pyramid (BoP), User context research

\section{INTRODUCTION}

\section{A. Healthcare design for rural China}

Oaning hina has a largest population in the world (1.3 Billion) and 0.9 Billion is rural population [1].They are composed of 0.75 Billion rural people who live in rural and 0.15 Billion who live in urban as migrant workers [2]. Although their average income increases every year to about 4000RMB/year (US\$1.4/day) at the end of 2006 [1], the income gap between rural and urban is becoming large year by year [3].

According to the World Bank (2005), there are 4 billion people living on an income less than US\$3 per day and 1 billion living less than even US\$1 per day. This part of the population is often called "Base-of-the-Pyramid" (BoP), referred by Prahalad and Hart $[4,5]$. And so more than $95 \%$ china rural belongs to BoP under this standard [1].

Recently a new research project has been initiated on "The Healthcare Design for China Rural BoP" leading to $\mathrm{PhD}$ of the first author of this paper. This paper is part of this work and the objective of this paper is to identify the healthcare needs of China rural through user context research in order to search for some healthcare design opportunities.

\section{B. User context research}

User context research is considered as the important way to get and balance needs for product improvement and some technologies are developed like recruiting and interviewing [6]. These technologies are concluded and innovated by the

Jiang Jiehui is a PhD candidate in Department of Design Engineering, Faculty of Industrial Design Engineering (IDE), Delft University of Technology, Netherlands. Address: Room 3A.42, Landbergstraat 15, 2628 CE Delft The Netherlands Phone:+31 (0) 152785730 E-Mail: J.Jiang@tudelft.nl

Prof. Dr. .P. V. Kandachar is also with this Faculty of Industrial Design Engineering. He is also Chairman of the Department of Design Engineering. E-mail: P.V.Kandachar@tudelft.nl.
School of Industrial Design Engineering (IDE) at Delft Technology of University (TUdelft)[7].

In this research, user context research also plays an important role in a twelve parts design methodology provided in last paper [8]. Two steps have direct relationship with it: User context research will result needs analysis because needs may be found through it and product design will make a feedback for user context research, as well as an evolution through user test. (Figure 1)

A three month user context research in healthcare design for rural China has been done at June, July and August of 2005, which is sponsored by Philips Medical Systems and Applied Technologies. Related qualitative researches and quantitative researches are carried out through field study in rural Shanghai, by a student team of Tudelft and Shanghai Univeristy. [9]

Recently, some Multi National Companies (MNC) such as HP, Intel, Philips and Microsoft have been aware of the design opportunities of this market, as well as some design institutes such as Delft University of Technology (DUT), Illinois Institute of Technology (IIT), Berkley and Standford

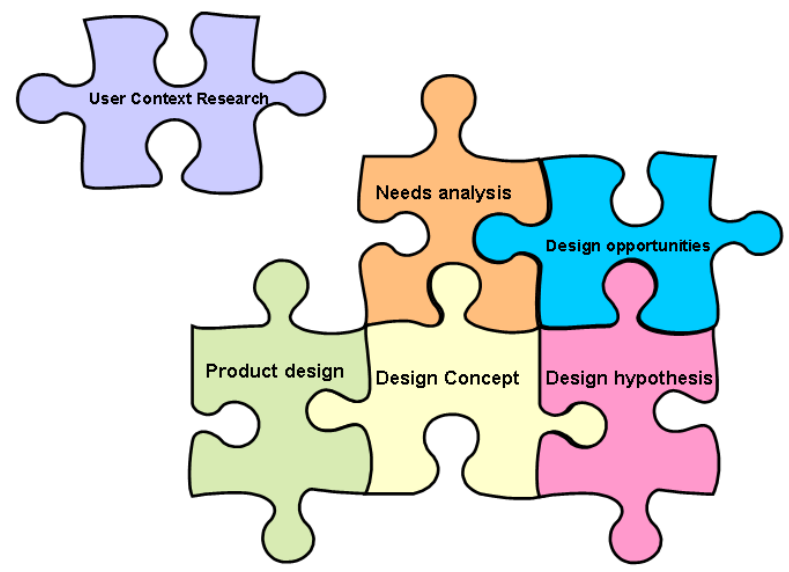

Figure 1: The relationship among user context research and other parts which are partnering with MNCs for BoP design.

\section{RESEARCH PROCESS, APPROACH AND RESUlTS}

\section{A. Research Process}

Similar with existing research process "Process of Conceptualization and Carrying out a Research"[7], a research process named "From Unstructured to Structured" has been designed by teammate Jan Pieter Adriaanse and Jaap Daalhuizen.(Figure 2)

In this research process, Primary/Second hand data is collected firstly through related research partners: Shanghai University, Tudelft and Philips and referred official data: statistic from World Health Organization.(WHO) These data 
are structured accurate up to date, which compose of

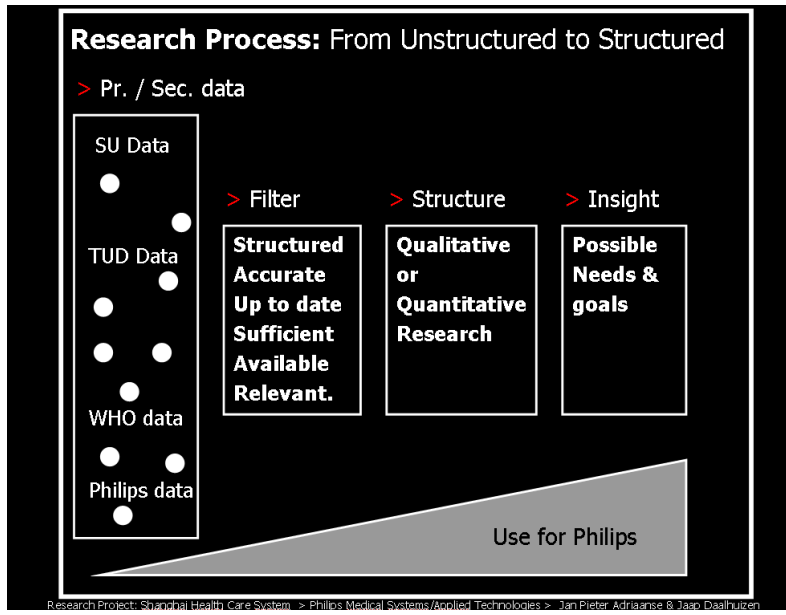

Figure 2: Research Process of User context research in rural Shangha

background knowledge and experienced tool for researchers. Qualitative and Quantitative research will be done to analyze and structure research data and insight on possible needs and goals will be found through this research.

\section{B. Qualitative research}

To gain initial insights on healthcare needs, a qualitative exploratory research has been carried out in Chongmin island, rural Shanghai. The main approach is based upon the observation of the customs, habits and differences between people in everyday situations and four tools are used:

$>$ Seeing through the eyes

$>$ Diaries

$>$ Semi structured interviews

$>$ Unstructured observations

Target rural people are divided into five types in this research: elderly, farmer, worker, housing women and child. And the output of this step is 5 personas.

Personas are archetypal users with specific goals and needs on real market and design research. They each represent a characteristic group of users, like 'workers' or 'farmers' [10]

Following factors are included in our personas:

$>$ A name

$>$ A photograph

$>$ Demographic characteristics

$>$ Techno graphic characteristics

$>$ Behavioural characteristics

$>$ Barriers and/or challenges

$>$ Specific goals and needs

To approach nature status for target group, five rules are used for interviews:

$>$ Almost develop an empathy with the respondent

$>$ Make sure the respondent is relaxed and comfortable

$>$ Be personable to encourage and motivate respondents

$>$ Note issues that interest the respondent and develop questions around these issues

$>$ Not be happy to accept brief 'yes' or 'no' answers.

Figure 3 shows a finished persona of elderly in Chongmin, which is composed of four parts: Introduction, Living conditions, Awareness and Needs. Pictures are added to help understand contents for readers and a special topic is there: "I am quite satisfied with my life; it has always been like this. I hope my grandchildren have a better life." And this thought will be considered in an interaction healthcare design for rural China as culture factors. The needs of personas are looked as main outputs for future research and they are recorded as

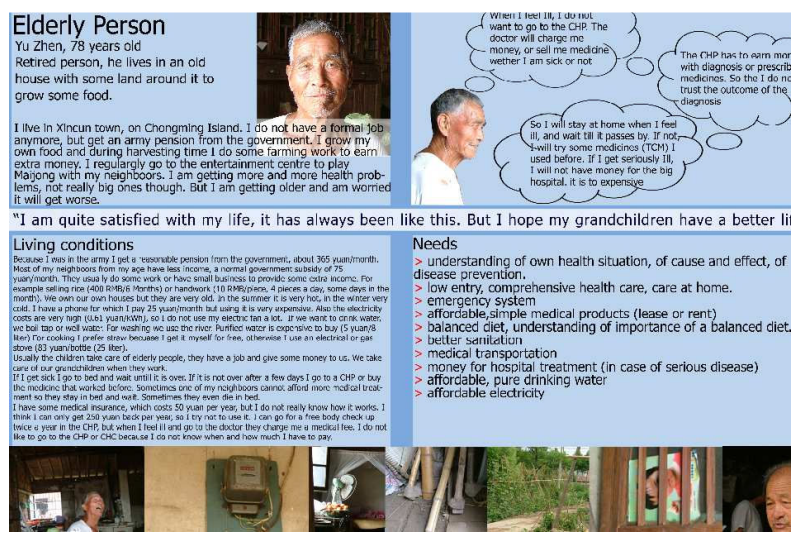

Figure 3: Persona of elderly

Edited by Jan, Jaap and Jiang

\section{Quantitative research}

The aim of quantitative research in this research is for unproven problem diagnosis. Some hypotheses have been found through persona such as "care at home" for elderly; however this hypothesis will be detected by other target elderly group. And then the factor or phenomena can be the evidence for researchers. Questionnaires are designed as quantitative research tools here.

1) Questionnaire design

Three special objectives are confirmed before the design:

$>$ It must translate the information needed into a set of specific questions that the respondent can and will answer;

$>$ Must uplift, motivate and encourage the respondent to become involved in the interview;

$>$ It must minimise response error.

Figure 4 shows the design process of questionnaires in this research. The contents of questions are chosen from qualitative research and they are specified into a type of

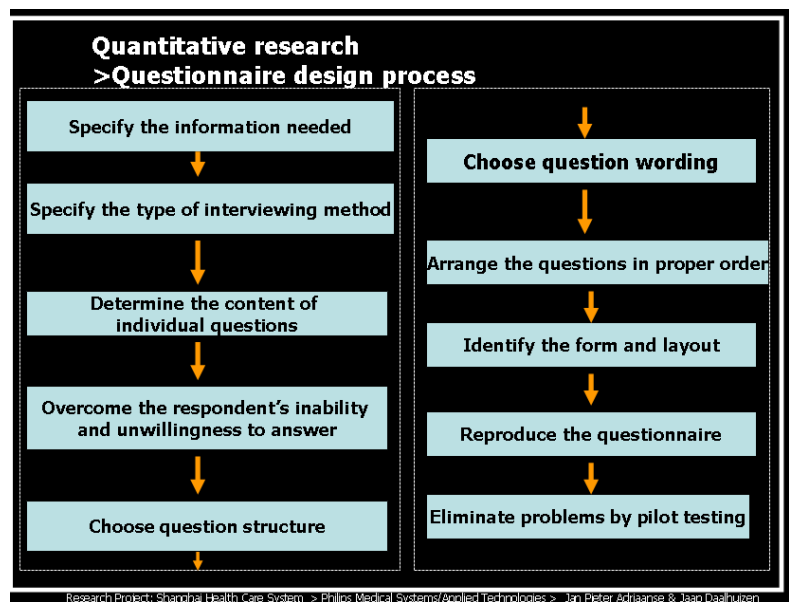

Figure 4: Ouestionnaire design process 
interviewing method, after a makeup in structure, wording, order and layout, totally 64 questions are set up and they are composed of: basic information(6), basic health information(10), health awareness(8), medical insurance(8) and healthcare needs(32). 50 example questionnaires had been tested in Chongmin as pilot test. (10 for every persona)

2) Respondents

Five different rural areas: Jinshan, Qingpu, Fengxian,

TABLE I

RESPONDENTS OF QUESTIONNAIRE

\begin{tabular}{|c|c|c|c|c|c|}
\hline Area & $\begin{array}{l}\text { Responden } \\
\text { t type }\end{array}$ & $\begin{array}{l}\text { No of } \\
\text { feedback }\end{array}$ & $\begin{array}{l}\text { Area } \\
\text { totally }\end{array}$ & $\begin{array}{l}\text { Responden } \\
\text { t totally }\end{array}$ & Plan \\
\hline \multirow{5}{*}{$\begin{array}{l}\text { Jin } \\
\text { Shan }\end{array}$} & farmer & 118 & \multirow{5}{*}{288} & farmer & farmer \\
\hline & worker & 27 & & \multirow{4}{*}{632} & \multirow{4}{*}{650} \\
\hline & elderly & 30 & & & \\
\hline & $\begin{array}{l}\text { Housing } \\
\text { woman }\end{array}$ & 97 & & & \\
\hline & child & 16 & & & \\
\hline \multirow{5}{*}{$\begin{array}{l}\text { Qing } \\
\mathrm{Pu}\end{array}$} & farmer & 135 & \multirow{5}{*}{276} & worker & worker \\
\hline & worker & 19 & & \multirow{4}{*}{125} & \multirow{4}{*}{150} \\
\hline & elderly & 32 & & & \\
\hline & $\begin{array}{l}\text { Housing } \\
\text { woman }\end{array}$ & 77 & & & \\
\hline & child & 13 & & & \\
\hline \multirow{5}{*}{$\begin{array}{l}\text { Feng } \\
\text { Xian }\end{array}$} & farmer & 127 & \multirow{5}{*}{277} & elderly & elderly \\
\hline & worker & 33 & & \multirow{4}{*}{148} & \multirow{4}{*}{200} \\
\hline & elderly & 28 & & & \\
\hline & $\begin{array}{l}\text { Housing } \\
\text { woman }\end{array}$ & 77 & & & \\
\hline & child & 11 & & & \\
\hline \multirow[t]{5}{*}{$\begin{array}{l}\text { Nan } \\
\text { Hui }\end{array}$} & farmer & 134 & \multirow{5}{*}{289} & $\begin{array}{l}\text { Housing } \\
\text { woman }\end{array}$ & $\begin{array}{c}\text { Housing } \\
\text { woman }\end{array}$ \\
\hline & worker & 21 & & \multirow{4}{*}{437} & \multirow{4}{*}{400} \\
\hline & elderly & 22 & & & \\
\hline & $\begin{array}{l}\text { Housing } \\
\text { woman }\end{array}$ & 94 & & & \\
\hline & child & 18 & & & \\
\hline \multirow{5}{*}{$\begin{array}{l}\text { Song } \\
\text { Jiang }\end{array}$} & farmer & 118 & \multirow{5}{*}{289} & child & child \\
\hline & worker & 25 & & \multirow{4}{*}{77} & \multirow{4}{*}{100} \\
\hline & elderly & 36 & & & \\
\hline & $\begin{array}{l}\text { Housing } \\
\text { woman }\end{array}$ & 91 & & & \\
\hline & child & 19 & & & \\
\hline
\end{tabular}

Nanhui and Songjiang have been chosen as questionnaire areas. 300 questionnaires are sent to each area by team and they will be back at the second day, so totally 1500 questionnaires are finished in this research.

Table 1 shows the respondents detail of this research, five target groups are separated. In this research, totally 1419 questionnaire are given back and the rate is $94.6 \%$. The highest area is Nanhui and Songjiang(96.3\%) and the lowest area is Qingpu. (92\%)

For the respondent types, farmer gets a highest rate $44.5 \%$ and child is least $5.4 \%$, the real number is acceptable according to plan.

3) Question description

Totally 64 questions are designed in this study, and they will divide into five parts:

$>$ Basic personal information (6): Name, gender, age, address, contact phone and Email

$>$ Basic health information (10): like Infectious disease history, impatient history
Health awareness (8): like "I will trust Village Doctor more if they have advanced product"

$>$ Medical Insurance (8): like "A good medical insurance will let me approach higher quality health care service"

Healthcare Needs (32): like "I prefer to monitoring my body vital signals at home (Temperature, blood pressure)" and more details can be found in table 2 .

Most of answers of questions are choices and only a little will be formed by respondents themselves. Commonly five choices are given like "Very agree", "agree", "no sense", "not agree" and "reject"., and the result will be imputed into the computer as "5", “4”, "3", "2" and " 1 ".

TABLE II

\begin{tabular}{|c|c|c|}
\hline \multicolumn{3}{|c|}{ STATISTICAL DISTRIBUTION OF RESPONDENTS } \\
\hline Needs & Needs description & Target Group \\
\hline $\begin{array}{l}\text { Common diseases } \\
\text { treatment } \\
\text { (4) }\end{array}$ & $\begin{array}{l}\text { Fever, cold, stomach and intestine } \\
\text { diseases } \rightarrow \text { Treatment }\end{array}$ & All \\
\hline $\begin{array}{l}\text { Cancer } \\
(6)\end{array}$ & $\begin{array}{l}\text { Lung caner(2), breast caner(2), } \\
\text { esophageal cancer, cervical cancer } \\
\rightarrow \text { early detection and treatment }\end{array}$ & $1,2,3,5$ \\
\hline $\begin{array}{l}\text { Heart Diseases } \\
\text { and blood vessel } \\
\text { for brain (2) }\end{array}$ & $\begin{array}{l}\text { Immediate treatment and } \\
\text { prevention }\end{array}$ & $1,2,3,5$ \\
\hline $\begin{array}{l}\text { Chronic disease } \\
\text { (6) }\end{array}$ & $\begin{array}{l}\text { High blood pressure, high blood } \\
\text { sugar and high blood fat } \rightarrow \\
\text { monitoring and personal care }\end{array}$ & 5 \\
\hline Nutrition (1) & $\begin{array}{l}\text { Nutrition detection for kids under } \\
1 \text { year old }\end{array}$ & 4 \\
\hline $\begin{array}{l}\text { Injury, Poisoning } \\
\& \text { External Causes } \\
\text { (2) }\end{array}$ & Care and treatment & All \\
\hline Tuberculosis (3) & $\begin{array}{l}\text { Prevention, detection and } \\
\text { treatment }\end{array}$ & All \\
\hline $\begin{array}{l}\text { Diseases of the } \\
\text { Respiratory } \\
\text { System (2) }\end{array}$ & Diagnosis and treatment & All \\
\hline $\begin{array}{lr}\text { Low } & \text { cost } / \text { safe } \\
\text { medical } & \text { service } \\
(3) & \\
\end{array}$ & $\begin{array}{l}\text { Current three types of low cost } \\
\text { medical service can't satisfy them }\end{array}$ & All \\
\hline $\begin{array}{l}\text { Pregnant \& Birth } \\
\text { (3) }\end{array}$ & $\begin{array}{l}\text { Pregnant care, birth care and } \\
\text { mother care for new birth }\end{array}$ & 2,5 \\
\hline
\end{tabular}

4) Data analysis

Two steps are used to look for error questionnaire in this research, which may be copied by same respondents.

a) Similar comparison: Of 32 questions about healthcare needs, the questionnaire will be ignored if more than 30 answers are same.

b) Complete decision: Of totally 64 questions, the questionnaire will be if ignored if more than 12 questions are skipped.

As a result, 1768 questionnaires are remained for next analysis.

To confirm the healthcare needs, all results of 32 questions are inputted into a $32 * 1768$ matrix (Figure 5): 


\begin{tabular}{|c|c|c|c|c|c|c|}
\hline & 1 & 2 & 3 & $\ldots \ldots$ & 31 & 32 \\
\hline 1 & $\mathrm{X}_{11}$ & $\mathrm{X}_{12}$ & $\mathrm{X}_{13}$ & $\ldots \ldots$ & $\mathrm{X}_{131}$ & $\mathrm{X}_{132}$ \\
\hline$\vdots$ & $\mathrm{X}_{21}$ & $\mathrm{X}_{22}$ & $\mathrm{X}_{23}$ & $\ldots \ldots$ & $\mathrm{X}_{231}$ & $\mathrm{X}_{232}$ \\
\hline 1767 & $\mathrm{X}_{\mathrm{i} 1}$ & $\mathrm{X}_{\mathrm{i} 2}$ & $\mathrm{X}_{\mathrm{i} 3}$ & $\ldots \ldots$ & $\mathrm{X}_{\mathrm{i} 31}$ & $\mathrm{X}_{\mathrm{i} 32}$ \\
\hline 1768 & $\mathrm{X}_{\mathrm{i} 1}$ & $\mathrm{X}_{\mathrm{i2}}$ & $\mathrm{X}_{\mathrm{i3}}$ & $\ldots \ldots$ & $\mathrm{X}_{\mathrm{i} 31}$ & $\mathrm{X}_{\mathrm{i} 32}$ \\
\hline Sum & $\mathrm{S}_{1}$ & $\mathrm{~S}_{2}$ & $\mathrm{~S}_{3}$ & $\ldots \ldots$ & $\mathrm{S}_{31}$ & $\mathrm{~S}_{32}$ \\
\hline Mean & $\mathrm{M}_{1}$ & $\mathrm{M}_{2}$ & $\mathrm{M}_{3}$ & $\ldots \ldots$ & $\mathrm{M}_{31}$ & $\mathrm{M}_{32}$ \\
\hline SD & $\mathrm{SD}_{1}$ & $\mathrm{SD}_{2}$ & $\mathrm{SD}_{3}$ & $\ldots \ldots$ & $\mathrm{SD}_{31}$ & $\mathrm{SD}_{32}$ \\
\hline
\end{tabular}

Figure 5: The matrix for data analysis

Where $S_{i}=\sum_{j=1}^{32} X_{i j}, M_{i}=S_{i} / 32$ and $S D_{i}=\sqrt{\frac{\sum_{j=1}^{32}(X I J-M i)^{2}}{32}}$ $\mathrm{M}$ of the statistic means the important level of needs for target group and SD means agreement of the M, and the head ten results of $\mathrm{M}$ are showed in table 3. (The same $\mathrm{M}$, small SD will be preferred)

TABLE III

THE RESULTS OF STATISTIC

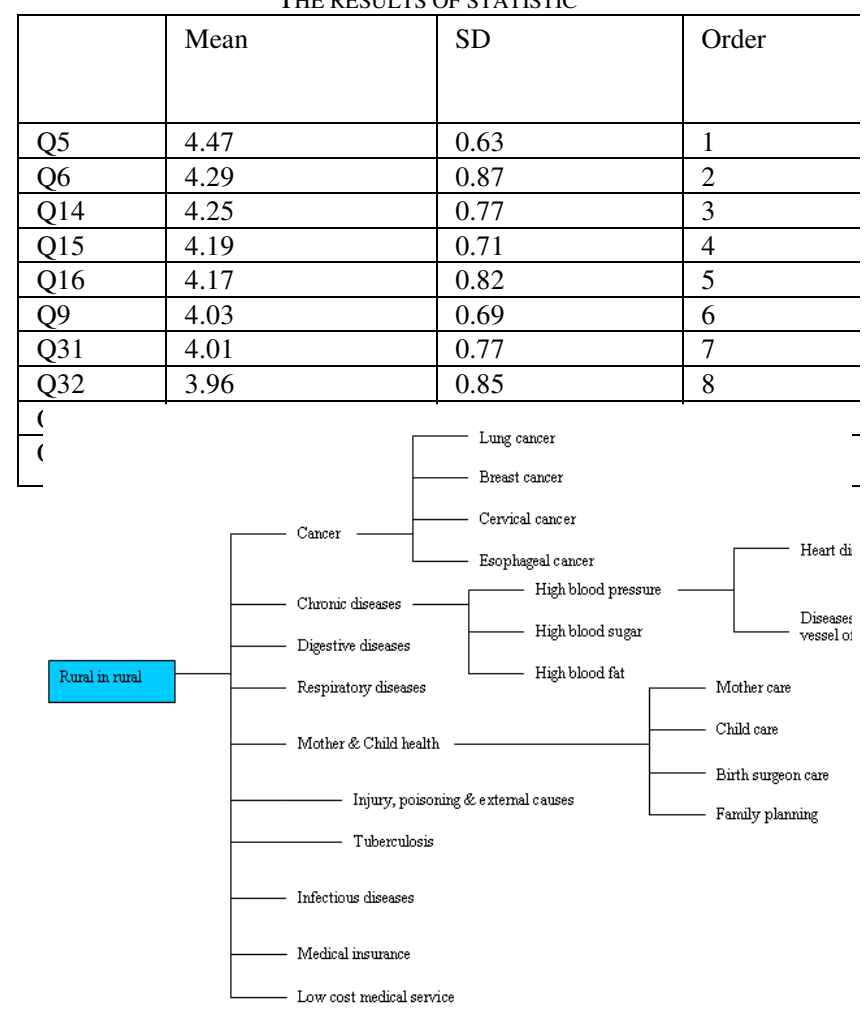

Figure6: The overview of healthcare needs in rural China

Q5: Early detection for lung cancer

Q9: Early detection for esophageal cancer

Q6: Treatment for lung cancer

Q31: Birth care
Q14: Blood pressure personal care

Q32: Care for new birth

Q15: Blood sugar measurement

Q7: Early detection for breast cancer

Q16: Blood sugar personal care

Q27: Improvement for Village healthcare points

All $\mathrm{M}$ of 32 questions are located between 3.7 and 4.5, which means all above healthcare needs are real and agreed by rural people. ( 3 is the average line)

\section{Insights: healthcare needs for China rural}

Based on above research process, three topics are chosen as preferred research fields: "Early detection for cancer", "Chronic diseases" and "Mother and Child". As a result, the overview of healthcare needs for China rural can be found in Figure 6. These needs will be analyzed later and result in some design opportunities, but the process will be discussed in future research paper.

\section{CONCLUSION}

A user context research on China rural healthcare needs is introduced in this paper. The research is mainly composed of qualitative research and quantitative research, and the research process is desktop research $\rightarrow$ Interviews $\rightarrow$ Personas $\rightarrow$ Questionnaires $\rightarrow$ Insights. These healthcare needs are proven through data analysis and the final results can be seen above. This research is part of social research of a $\mathrm{PhD}$ topic and other steps will be discussed in future research paper.

\section{REFERENCES}

[1] National National Bureau of Statistics of China, China Statistical Yearbook2007.

[2] Leslie T. Chang, Migrant worker in China, Wall Street Journal. (Eastern edition).New York, N.Y.: Nov 8, 2004. pg. A.1

[3] John Whalley Xinming Yue, Rural Income Volatility and Inequality in China, NBER working paper series, 2006, No 12779.

[4] Prahalad C.K and Hart, S.L., (2002) Strategy + Business, Issue 26, www.digitaldividend.org/pdf/bottompyramid.pdf

[5] "Fortune at the Bottom of the Pyramid, The: Eradicating Poverty Through Profits" (Publisher: Wharton School Publishing, 2005, ISBN-10: 0-13-187729-1, ISBN-13: 978-0-13-187729-0, Pages: 304)

[6] Mike Kuniavsky, Observing the User Experience: A Practitioner's Guide to user research, Morgan Kaufmann publisher, 2003, Page 35-46, 57-87.

[7] René van Egmond, Quantitative Methods: An Overview, Presentation, 2005

[8] Jiang Jiehui and Prabhu Kandachar, New Market, New Challenge, New Market (1): Overview of China rural healthcare \& Design methodology (Submitted), 2008

[9] Jiang Jiehui and Jennifer Flexman, Shanghai University club uses technology to fight poverty, IEEE Engineering in Medical and Biology Magazine. 26 (2):10-1 17441603

[10] Thomas C. Kinnear and James R. Taylor. Marketing research an applied approach. McGraw-Hill Companies(5th edit, 1995), ISBN:0079122523 Page 115. 